\title{
Penyuluhan Pengetahuan Tentang Instalasi Listrik dan Mengoptimalkan Penggunaannya Serta Mengatasi Bahaya Listrik Bagi Masyarakat Di Wilayah Duri Kosambi, Cengkareng Jakarta Barat
}

\author{
Tony Koerniawan ${ }^{1}$; Isworo Pujotomo ${ }^{2}$; Muchamad Nur Qosim ${ }^{3}$; Aas Wasri Hasanah ${ }^{4}$; \\ Rinna Haryanti ${ }^{5}$; Christine Widyastuti ${ }^{6}$; Oktaria Handayani ${ }^{7}$ \\ 1, 2, 3, 4, 5, 6,7 Fakultas Ketenagalistrikan dan Energi Terbarulan, Institut Teknologi PLN \\ ${ }^{1}$ tonykoerniawan84@gmail.com
}

\begin{abstract}
Electricity is the most suitable and appropriate form of energy for modern human life, such as today, where electrical energy has a function that can provide a need or service for electric power obtained by consumers, with electricity human life becomes very pleasant. Television, lighting, traffic lights, all using electricity. So, electricity can be said as a form of technological results that are very vital in human life. With this activity, it is expected that the general public can and understand about safe electrical installation and handling, mitigation of electrical hazards that are not in accordance with $P L N$ 's standardization. So that electricity does not necessarily become a scapegoat every time there is a fire in the community, and the voltage system used in Indonesia is: single phase $220 \mathrm{~V}$, and phase three 220/380 V with a frequency of $50 \mathrm{~Hz}$. This voltage system is very influential and dangerous for human safety.
\end{abstract}

Keywords: cable, voltage, current, installation, short circuit

\begin{abstract}
ABSTRAK
Listrik merupakan bentuk energi yang paling cocok dan tepat bagi kehidupan manusia modern seperti dewasa ini, dimana energi listrik mempunyai fungsi yang dapat memberikan suatu kebutuhan atau pelayanan daya listrik yang diperoleh oleh konsumen, dengan listrik kehidupan manusia menjadi sangat menyenangkan. Televisi, lampu penerangan, lampu lalu lintas, semua menggunakan listrik. Jadi, listrik dapat dikatakan sebagai suatu bentuk hasil teknologi yang sangat vital dalam kehidupan manusia. Dengan kegiatan ini, maka diharapkan masyarakat umum bisa dan paham tentang instalasi listrik yang aman dan penanganan, penanggulangan dari bahaya listrik yang tidak sesuai dengan standarisasi PLN. Sehingga listrik tidak serta merta menjadi kambing hitam setiap saat ada kejadian kebakaran di lingkungan masyarakat, dan sistem tegangan yang digunakan di Indonesia adalah: fasa-tunggal $220 \mathrm{~V}$, dan fasa-tiga 220/380 V dengan frekuensi $50 \mathrm{~Hz}$. Sistem tegangan ini sangat mempengaruhi dan berbahaya bagi keselamatan manusia.
\end{abstract}

Kata kunci: kabel, tegangan, arus, instalasi, konsleting 


\section{PENDAHULUAN}

Melihat dan mendengar dan berbagai media, listrik selalu menjadi pokok permasalahan dari konsleting listrik dan menyebabkan kebakaran. "Lebih dari 70 persen kebakaran terjadi akibat korsleting listrik. Korsleting adalah hubungan arus pendek yang terjadi dalam sebuah jaringan/instalasi. Hal ini karena ketidakmampuan instalasi/jaringan untuk menahan arus listrik, Artinya, kemungkinan instalasi yang ada di sebuah gedung bisa saja sudah tua, atau di bawah standar ataupun pemilik telah mengubah-ubah standar yangg telah ditetapkan. Banyaknya colokan dalam satu fitting saluran kabel juga dapat menyebabkan korsleting listrik. Yang lebih berbahaya lagi apabila sistem pengaman (MCB) instalasi di dalam bangunan tidak dapat berfungsi dengan baik, maka dapat berakibat kebakaran.

Agar kebakaran tidak terjadi akibat korsleting listrik, seharusnya sebuah bangunan harus memiliki SLO (Surat Laik Operasi) yang diterbitkan Konsuil dan masyarakat atau pemilik bangunan tidak mengubah-ubah standar yang telah ditetapkan di dalam SLO tersebut. Selain itu masyarakat juga harus memperhatikan instalasi dalam rumah. Kita harus mengetahui bahwa instalasi dalam rumah adalah tanggung jawab pemilik rumah. PLN selalu memasang alat pada kwh meter sehingga apabila terjadi arus pendek atau korslet maka seluruh listrik di rumah tersebut otomatis padam. Namun ada juga saat di mana alat kwh tidak bekerja ketika korslet terjadi, ini akibat jika MCB diutakatik sendiri. Apalagi jika pelanggan menyambung sendiri aliran dari jaringan seperti yang sering dilakukan untuk pos keamanan. Ini juga berbahaya karena tanpa pengaman.

\section{KAJIAN LITERATUR}

Sambungan rumah adalah sambungan jaringan listrik dari tiang TR (tegangan rendah) ke tiang atap dari konsumen pengguna listrik lainnya untuk disalurkan kerumah konsumen yang memerlukan suplay energy listrik.

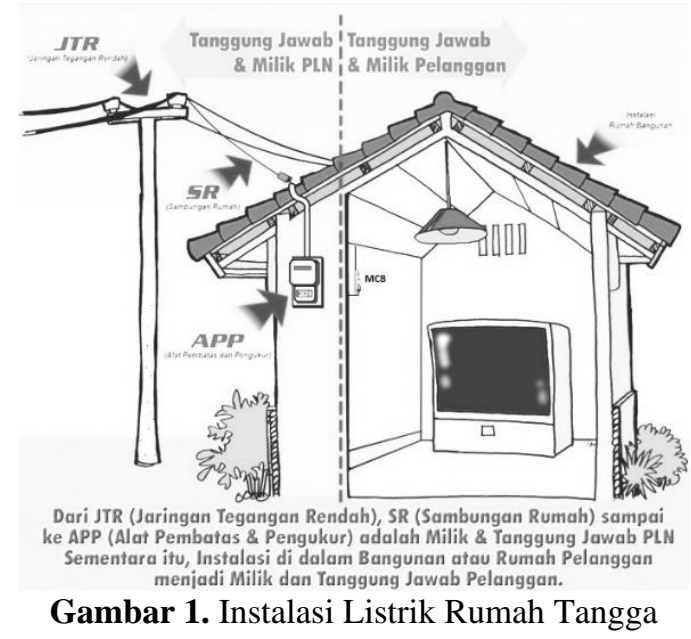

\section{a. KOMPONEN SAMBUNGAN RUMAH}

Adapun komponen yang tersambung di dalam rumah antara lain:

1. Saluran Rumah, yaitu instalasi listrik mulai dari tiang sampai ke APP ( alat pengukur dan pembatas )

2. APP, yaitu KWH meter ( Bargainser ) sebagai alat pengukur (pencatat) jumlah energi yang dikonsumsi dan alat pembatas MCB ( magnetic circuit breaker). Alat pembatas berfungsi untuk membatasi arus maksimum yang boleh mengalir ke seluruh beban. 
3. Saluran utama, yaitu instalasi listrik mulai dari APP sampai ke PHB (papan hubung bagi) utama.

4. PHB, berisi alat pengaman terhadap hubung singkat.

5. Sirkit cabang, adalah instalasi listrik antara PHB utama sampai PHB cabang.

6. Sirkit akhir adalah instalasi lsitrik antara PHB dan pemakai (beban).

\section{b. Peralatan Listrik Rumah Tinggal}

1. APP (Alat Pengukur Pembatas) / Bargainser

2. Fungsi Bargainser : Pembatas daya listrik yang masuk ke rumah tinggal dan Pengukur jumlah energi listrik yang digunakan rumah tinggal tersebut. Ada berbagai batasan daya yang dikeluarkan oleh PLN untuk konsumsi rumah tinggal, yaitu 220 VA, 450 VA, 900 VA, 1300 VA, dan 2.200 VA.

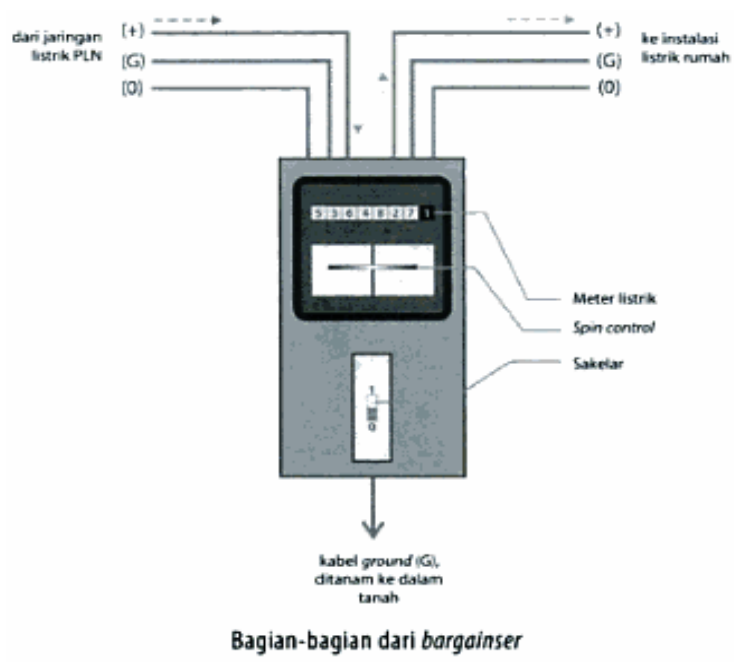

Gambar 2. Alat Pengukur pembatas (Bargainser)

\section{c. PENGAMAN LISTRIK}

Untuk memutuskan rangkaian listrik apabila terjadi gangguan pada instalasi listrik rumah tinggal tersebut, seperti gangguan hubung singkat atau short circuit atau korsleting.

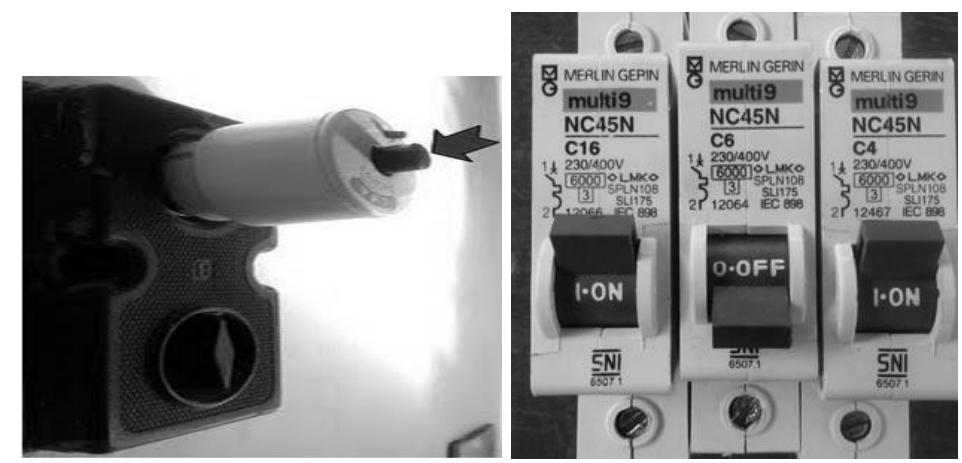

Gambar 3. Pengaman Lebur dan Otomatis (elektrik) 


\section{d. SAKELAR}

Sakelar atau switch berfungsi untuk menyambung atau memutus aliran listrik pada suatu penghantar.
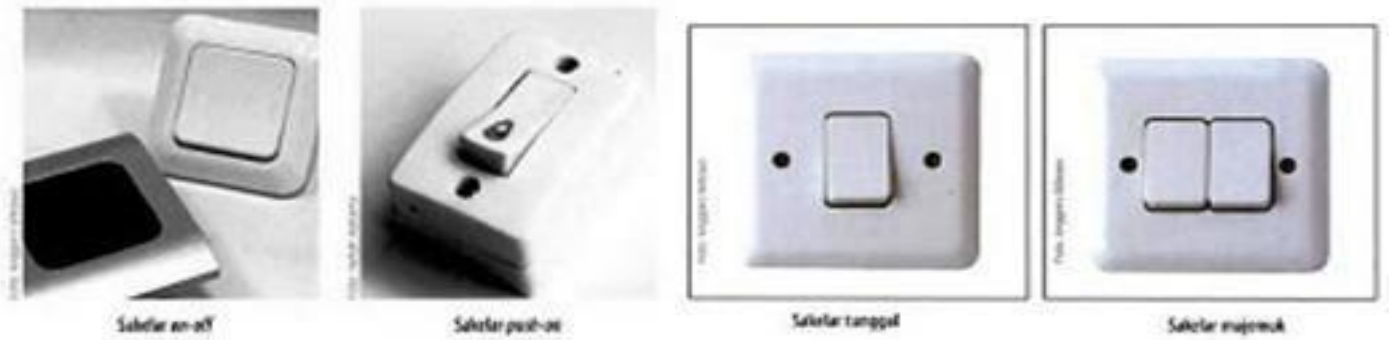

Gambar 4. Macam dan Model Saklar

\section{e. STOP KONTAK}

Bagian terminal akhir dari instalasi listrik rumah yang terpasang permanen sebagai penghubung yang menyalurkan energi listrik ke beban atau peralatan listrik.

\section{f. STEKER}

Berdasarkan fungsi dan bentuknya, steker dibedakan menjadi dua jenis, yaitu:

1. Steker kecil, merupakan steker yang digunakan untuk menyambung alat-alat listrik berdaya rendah, misalnya lampu atau radio kecil, dengan sumber listrik atau stop kontak.

2. Steker besar, merupakan steker yang digunakan untuk alat-alat listrik yang berdaya besar, misalnya lemari es, microwave, mesin cuci dan lainnya, dengan sumber listrik atau stop kontak. Steker jenis ini dilengkapi dengan lempeng logam untuk kanal ground yang berfungsi sebagai pengaman.

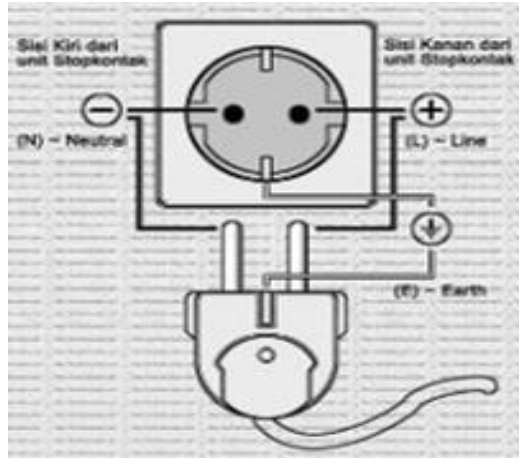

Gambar 5. Ilustrasi Steker dan Stop kontak

\section{g. KABEL}

Kabel listrik merupakan komponen listrik yang berfungsi untuk menghantarkan energi listrik ke sumber-sumber beban listrik atau alat-alat listrik. Untuk instalasi listrik rumah tinggal, kabel yang digunakan biasanya berjenis sebagai 

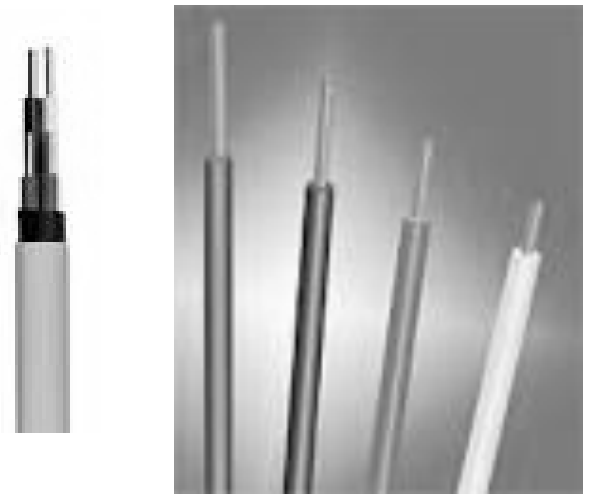

Gambar 6. Bentuk Kabel

\section{h. PENANGKAL PETIR}

Adalah rangkaian jalur yang difungsikan sebagai jalan bagi petir menuju ke permukaan bumi, tanpa merusak benda-benda yang dilewatinya. Ada 3 bagian utama pada penangkal petir:

a. Batang penangkal petir

b. Kawat konduktor

c. Tempat pembumian

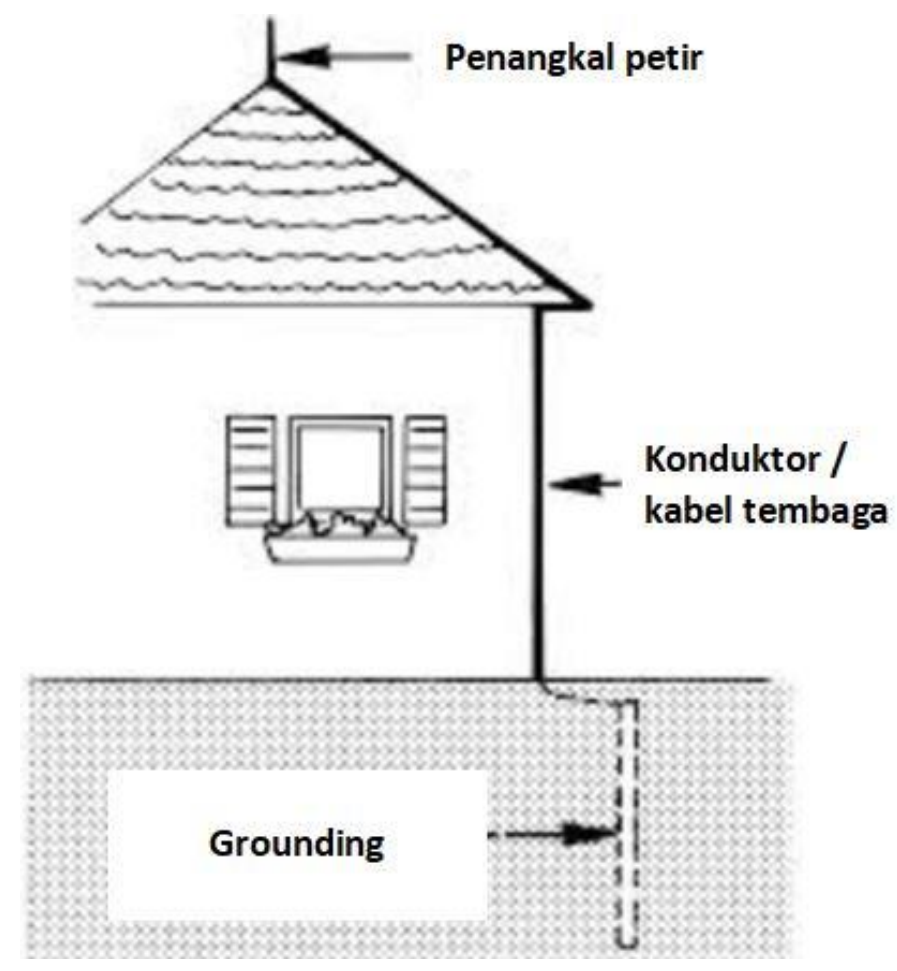

Gambar 7. Sistem Penangkal petir 


\section{METODE PELAKSANAAN}

Metode pelaksanaan yang digunakan dalam pelaksanaan P2M ini adalah :

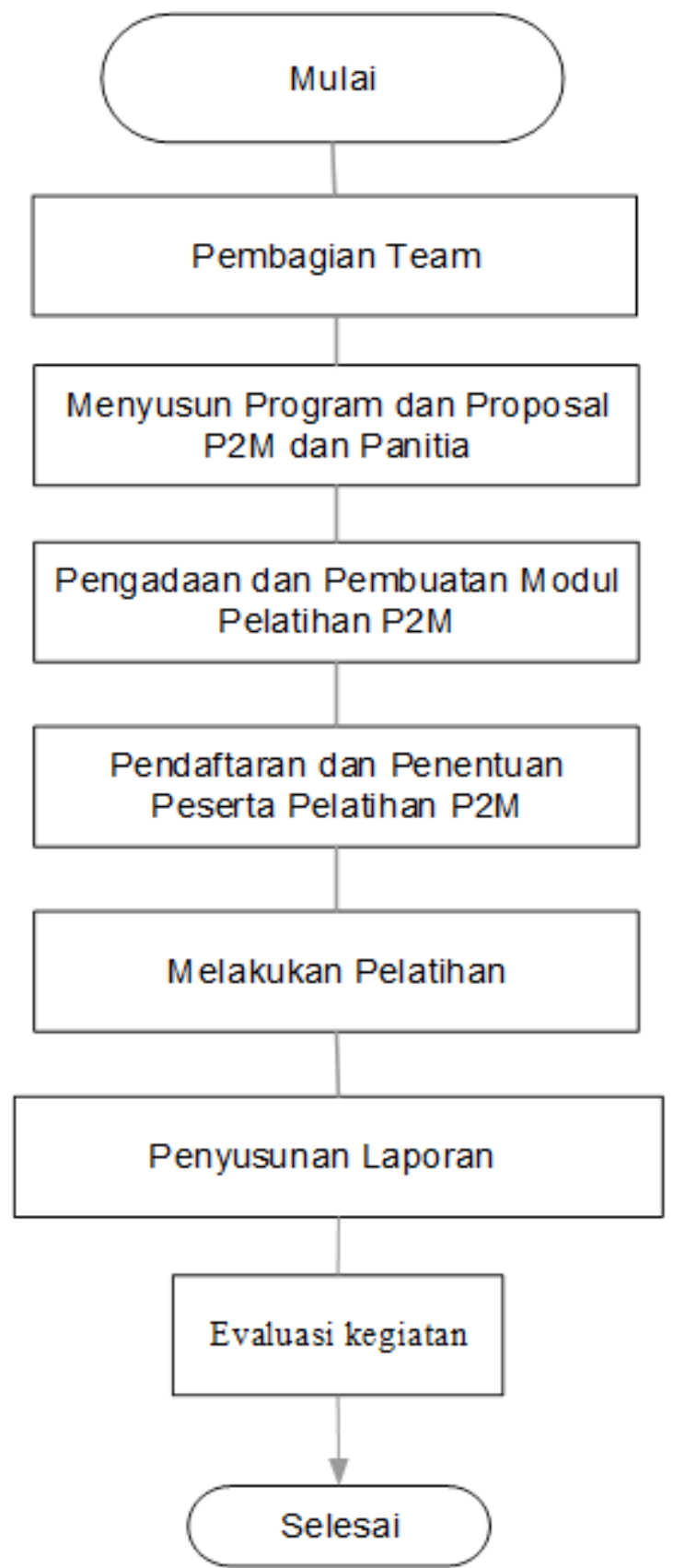

Gambar 8. Diagram Alir Kegiatan P2M

\section{HASIL DAN PEMBAHASAN}

Kegiatan penyuluhan pengetahuan tentang instalasi listrik dan mengoptimalkan penggunaanya serta mengatasi bahaya listrik bagi masyarakat di wilayah duri kosambi, cengkareng jakarta barat, Kegiatan sosialisasi berjalan dengan lancar dihadiri oleh 40 peserta yang terdiri dari warga dan perangkat rt/rw setempat serta dosen panitia itu sendiri. Peserta sosialisasi terlihat antusias dengan materi yang diberikan. Hal ini terlihat dari awal hingga akhir acara, semua peserta mengikuti dengan baik, Kegiatan pengabdian pada masyarakat ini pertama 
di dahului dengan pemikiran lokasi yang dekat disekitar area kita bekerja yang mana bidang kita khususnya sttpln jurusan teknik elektro di kelistrikan dan merasa perlu di berikan penyuluhan tentang kelistrikan dari dasar pemikiran seperti itu. Dari situ maka kita team secara musyawarah mencuba mencari dan mensurvei daerah sekitar.

Atas alasan tersebut di atas, maka kami menetapkan lokasi yang akan di jadikan subyek kami. Kegiatan ini kami fokuskan pada apakah listrik dasar di rumah rumah atau tempat tinggal sendiri sudah bisa memahaminya atau tidak, pengertian dasar listrik itu apa, komponen, peralatan dan bahan yang berhubungan dengan listrik serta kegunaan komponen listriknya, standart penempatan dan pemakaian listrik itu gimana, dan penanganan apabila listrik disalah gunakan alias ada konsleting listrik ataupun kebakaran karena panas listrik serta penanganan dari masalah itu serta antisipasi atau cara menghindari atau menjauhkan dari kebakaran karena listrik. Semua itu disosialisasikan di lingkungan terdekat untuk masyarakatnya dan lingkungan sekitar.

Adapun bentuk dari penyuluhan ini kita paparkan secara presentasi dan simulasi atau bentuk contoh kecil dari segala ilmu listrik dirumah tangga.

Berikut adalah foto-foto kegiatan penyuluhan:

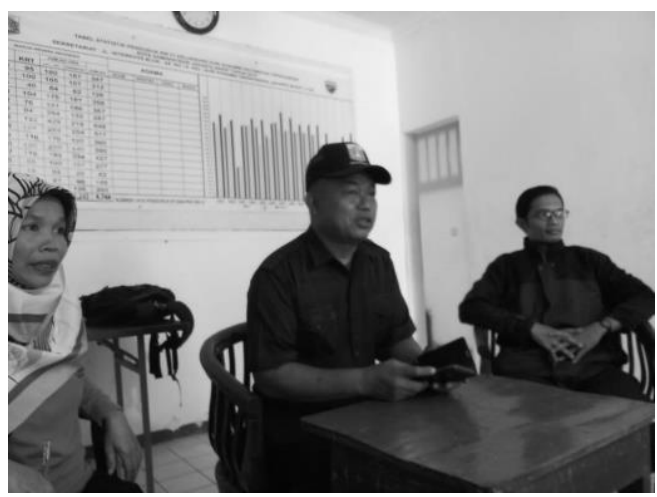

Gambar 9. Survei Tempat

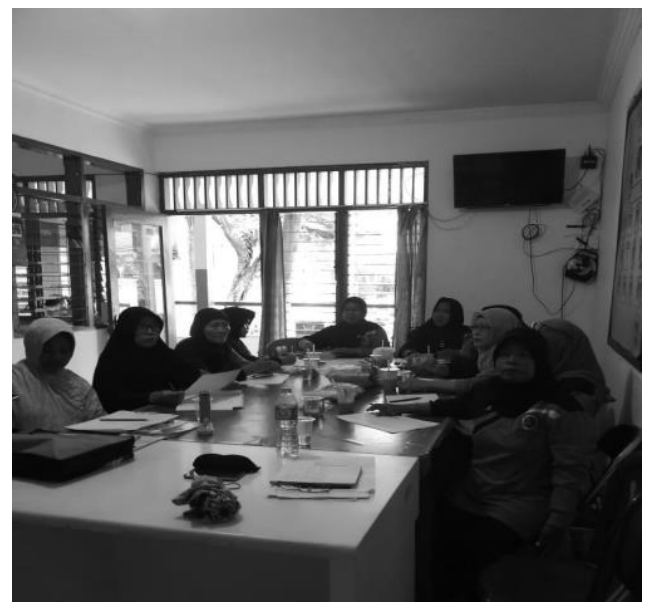

Gambar 10. Peserta Ibu-ibu PKK RW 07 Duri Kosambi 


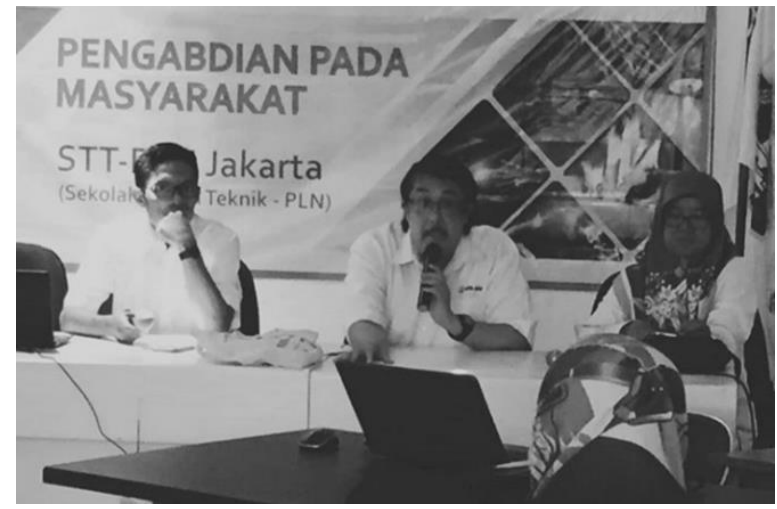

Gambar 11. Acara Pembukaan Penyuluhan

\section{KESIMPULAN DAN SARAN}

\subsection{Kesimpulan}

Mengacu pada rancangan kegiatan dan berdasarkan dari hasil kegiatan sosialisasi dapat disimpulkan bahwa:

1. Sosialisasi tentang penyuluhan Instalasi Listrik dan Pengoptimalan cara dan penggunaan listrik serta mengatasi bahaya listrik bagi masyarakat di wilayah Duri Kosambi, Cengkareng, Jakarta Barat. secara positif membawa manfaat akan peningkatan pengetahuan apakah itu dasar listrik secara pengetahuan umum dimasyarakat, manfaat apa saja yang dapat di ambil dari adanya pengetahuan dasar listrik.

2. Apakah instalasi listrik di rumah sudah sesuai dengan peraturan atau tidak, dan apakah bisa secara cepat andaikan ada permasalahan atau konsleting listrik di rumah sendiri.

3. Dari semua itu bisa mengoptimalkan secara penuh akan kebutuhan listrik di rumah tangganya.

\subsection{Saran}

1. STT-PLN perlu lebih menggalakkan dan meningkatkan program sosialisasi ataupun penyuluhan tentang instalasi listrik di rumah tangga.

2. Dukungan Pemerintah daerah juga diharapkan karena tidak memerlukan biaya yang besar untuk memberi ilmu dan pengarahan yang baik tentang listrik, manfaat dan pemakaiannya di masyarakat.

3. Serta diharapkan setiap wilayah RT ada ahli tentang penanganan bahaya listrik.

\section{UCAPAN TERIMA KASIH}

Dengan terlaksananya kegiatan ini TIM P2M mengucapkan banyak terima kasih kepada Allah SWT, dengan limpahan rahmat dan hidayahnya sehingga kami semua diberi kesehatan bisa dan dapat menyelesaikan dengan bagus dan baik semua kegiatan dari awal hingga akhir, juga tak lupa kami sampaikan kepada KLPPM STT-PLN atas Himbauan dan Bimbingannya, tak lupa juga terhadap Ketua RW 07 Duri Kosambi setempat beserta jajaran nya dan warganya yang tanpa dukungan dan bantuannya kami tidak dapat melaksanakan ini semua. Serta semua anggota TIM yang telah bekerjasama untuk mensukseskan kegiatan ini.

Semoga dari kegiatan ini semua mendapat kebaikkan dan keberkahan dari Allah SWT. Dan lupa bahwa kita ini hidup tidak lain menjadi orang berguna bagi orang lain. Demikian Laporan Akhir Pengabdian Pada Masyarakat ini kami buat semoga bermanfaat bagi kita dan pembacanya kelak. Aamiin. 
Terang: Jurnal Pengabdian Pada Masyarakat Menerangi Negeri Vol. 2, No. 2, Juli 2020

DOI: https://doi.org/10.33322/terang.v2i2.381
e-ISSN: 2655-5948

P-ISSN: 2655-5956

Hal. $100-108$

\section{DAFTAR PUSTAKA}

[1] Brian Scadan oleh penerbit Erlangga Edisi ke 12, 2004

[2] A.J What Kins, Perhitungan Instalasi Listrik, volume 3 oleh penerbi Erlangga, 2004

[3] PUIL (Persyaratan Umum Instalasi Listrik), 2016

[4] Gatut Susanta, Kiat Hemat Bayar Listrik oleh, penerbit Niaga Swadaya, 2007 